\title{
Propranolol in hypertension
}

\author{
S. N. TEWARI* \\ M.B., B.S. \\ Medical Registrar, \\ Wakefield Group of Hospitals
}

\author{
R. H. E. GRant $\dagger$ \\ M.B., B.S., D.C.H. \\ Medical Department, \\ Imperial Chemical Industries Ltd, \\ Pharmaceuticals Division, \\ Alderley Park, Macclesfield, Cheshire
}

\section{Summary}

Twenty-four hypertensive patients, eleven of whom had angina pectoris as well, have been treated with propranolol in doses up to $400 \mathrm{mg}$ daily. The thirteen patients without angina received methyldopa $2 \mathrm{~g}$ daily in addition to propranolol. A significant reduction of systolic and diastolic blood pressure was found in both groups.

Results from other authors are discussed.

\section{Introduction}

The hypotensive action of adrenergic betareceptor blockade was first observed by Prichard during early clinical trial of pronethalol in angina pectoris (Prichard et al., 1964). Prichard subsequently demonstrated this action with propranolol (Prichard \& Gillam, 1964). The present study was intended to examine these results.

\section{Methods}

Twenty-five hypertensive male patients aged between 47 and 67 years (mean 54.6) attending the long term anticoagulant and hypertensive clinic at the County and Clayton Hospital in Wakefield were included in the trial. One patient withdrew because of side-effects.

Eleven patients (Group 1) suffered from angina of effort, with or without myocardial infarction and were receiving glyceryl trinitrate tablets for attacks of angina. None of these patients had received any anti-hypertensive therapy previously. Three of them (Nos. 1,5 and 6) had suffered from ventricular tachycardia following myocardial infarction and were taking maintenance doses of quinidine sulphate, $200 \mathrm{mg} 8$ hourly, to prevent arrhythmia.

\footnotetext{
*Present address: The Royal Albert Edward Infirmary, Wigan.

+Present appointment: Director The David Lewis Epileptic Colony, Warford, Nr. Alderley Edge, Cheshire.
}

Thirteen patients (Group 2) had been receiving $\alpha$-methyldopa, $2 \mathrm{~g}$ daily, for 6 months without any reduction in their arterial blood pressures. In this group patients did not have angina and propranolol was added as an adjuvant therapy to methyldopa.

All patients had a full blood count, blood urea, liver function tests including serum transaminase, and routine examination of urine for pus cells, protein and casts, an X-ray of chest and intravenous pyelogram. These tests were repeated at the end of the trial. The patients were reviewed every 3 weeks for 12 weeks and body weight was recorded prior to the administration of the therapy and at each attendance. Blood pressure was recorded in three positions, lying, sitting and standing. Patients showing albuminuria, blood urea greater than $50 \mathrm{mg} /$ $100 \mathrm{ml}$ and retinal changes were not included in the trial. Propranolol was started at $80 \mathrm{mg}$ daily and the dose was gradually increased to $400 \mathrm{mg}$ daily in divided doses, when smaller doses failed to reduce the blood pressure satisfactorily. After the period of the trial, patients were followed up for 18 months and a satisfactory control was achieved with only minor adjustments in doses. No tolerance to the drug was observed during this period.

\section{Side-effects}

One patient felt 'heaviness' in the head and dizziness and stopped the treatment. Another complained of failure to concentrate but this gradually cleared up in spite of continuing treatment. Another patient who was refractory to previous hypotensive therapy (guanethidine) and had a blood pressure of 230/ $130 \mathrm{mmHg}$, showed signs of mental depression probably due to gross cerebral arteriopathy; there was no deterioration in mental state when propranolol was added. 
TABLE 1

Blood pressure of twenty-four patients with hypertension before and after treatment with propranolol

\begin{tabular}{|c|c|c|c|c|c|c|c|c|c|c|}
\hline \multirow{3}{*}{ Patient } & \multirow{3}{*}{ Age } & \multirow{3}{*}{$\begin{array}{l}\text { Maximum } \\
\text { dose of } \\
\text { propranolol } \\
\text { (mg/day) }\end{array}$} & \multirow{3}{*}{$\begin{array}{c}\text { Duration } \\
\text { of } \\
\text { trial } \\
\text { (weeks) }\end{array}$} & \multirow{3}{*}{$\begin{array}{l}\text { Duration of } \\
\text { maximum doses } \\
\text { at end of trial } \\
\text { (weeks) }\end{array}$} & \multicolumn{6}{|c|}{ Blood pressure } \\
\hline & & & & & \multicolumn{3}{|c|}{ Before propranolol } & \multicolumn{3}{|c|}{ On maximum dose of propranolo } \\
\hline & & & & & Lying & Sitting & Standing & Lying & Sitting & Standing \\
\hline \multicolumn{11}{|l|}{ Group 1} \\
\hline $1^{*}$ & 53 & 400 & 12 & 3 & $210 / 120$ & $210 / 120$ & $210 / 120$ & $190 / 100$ & $190 / 100$ & $190 / 100$ \\
\hline 2 & 57 & 400 & 12 & 3 & $190 / 100$ & $195 / 100$ & $190 / 100$ & $200 / 110$ & $200 / 110$ & $190 / 110$ \\
\hline 3 & 61 & 300 & 9 & 3 & $210 / 110$ & $210 / 110$ & $200 / 110$ & $180 / 90$ & $180 / 90$ & $180 / 90$ \\
\hline 4 & 59 & 400 & 12 & 3 & $225 / 130$ & $230 / 130$ & $225 / 130$ & $200 / 120$ & $200 / 110$ & $200 / 110$ \\
\hline $5^{*}$ & 49 & 240 & 12 & 3 & $180 / 110$ & $185 / 110$ & $180 / 110$ & $150 / 80$ & $140 / 80$ & $140 / 80$ \\
\hline $6^{*}$ & 50 & 400 & 12 & 3 & $195 / 115$ & $195 / 115$ & $195 / 115$ & $164 / 90$ & $165 / 90$ & $165 / 90$ \\
\hline 7 & 52 & 240 & 12 & 3 & $200 / 105$ & $200 / 105$ & $200 / 105$ & $185 / 90$ & $185 / 90$ & $180 / 90$ \\
\hline 8 & 57 & 240 & 12 & 3 & $210 / 110$ & $220 / 110$ & $220 / 110$ & $200 / 100$ & $200 / 100$ & $200 / 95$ \\
\hline 9 & 63 & 300 & 12 & 3 & $185 / 105$ & $185 / 105$ & $180 / 105$ & $150 / 90$ & $145 / 95$ & $145 / 90$ \\
\hline 10 & 67 & 400 & 12 & 3 & $210 / 100$ & $210 / 105$ & $210 / 105$ & $170 / 90$ & $170 / 90$ & $170 / 85$ \\
\hline 11 & 55 & 400 & 12 & 3 & $185 / 110$ & $195 / 115$ & $185 / 110$ & $170 / 100$ & $170 / 100$ & $165 / 95$ \\
\hline \multicolumn{11}{|l|}{ Group 2} \\
\hline 1 & 47 & 300 & 12 & 3 & $230 / 120$ & $230 / 120$ & $230 / 120$ & $210 / 105$ & $210 / 105$ & $210 / 100$ \\
\hline 2 & 59 & 300 & 12 & 3 & $220 / 115$ & $220 / 115$ & $220 / 115$ & $210 / 100$ & $210 / 105$ & $200 / 100$ \\
\hline 3 & 22 & 300 & 12 & 3 & $235 / 130$ & $230 / 130$ & $230 / 130$ & $200 / 100$ & $200 / 100$ & $195 / 105$ \\
\hline 4 & 61 & 300 & 12 & 3 & $215 / 125$ & $210 / 125$ & $210 / 120$ & $210 / 110$ & $200 / 110$ & $210 / 115$ \\
\hline 5 & 58 & 300 & 12 & 3 & $230 / 125$ & $230 / 125$ & $230 / 125$ & $215 / 115$ & $210 / 115$ & $200 / 110$ \\
\hline 6 & 51 & 300 & 12 & 3 & $190 / 115$ & $190 / 115$ & $120 / 115$ & $170 / 100$ & $170 / 100$ & $170 / 100$ \\
\hline 7 & 59 & 300 & 12 & 3 & $185 / 120$ & $180 / 120$ & $180 / 120$ & $165 / 100$ & $160 / 95$ & $165 / 100$ \\
\hline 8 & 61 & 300 & 12 & 3 & $200 / 120$ & $195 / 120$ & $195 / 120$ & $170 / 100$ & $170 / 100$ & $170 / 95$ \\
\hline 9 & 58 & 400 & 15 & 3 & $235 / 135$ & $230 / 130$ & $230 / 130$ & $230 / 130$ & $240 / 130$ & $230 / 130$ \\
\hline 10 & 56 & 400 & 15 & 3 & $220 / 125$ & $220 / 130$ & $220 / 125$ & $200 / 115$ & $200 / 110$ & $200 / 110$ \\
\hline 11 & 53 & 400 & 15 & 3 & $210 / 115$ & $210 / 115$ & $210 / 115$ & $190 / 90$ & $190 / 90$ & $185 / 90$ \\
\hline 12 & 48 & 400 & 15 & 3 & $190 / 130$ & $190 / 130$ & $190 / 130$ & $160 / 110$ & $160 / 105$ & $160 / 105$ \\
\hline 13 & 56 & 400 & 15 & 3 & $225 / 125$ & $230 / 125$ & $225 / 125$ & $220 / 120$ & $220 / 125$ & $215 / 120$ \\
\hline
\end{tabular}

Group 1: Angina and hypertension-no previous hypotensive therapy.

Group 2. Hypertension alone - previous and concomitant treatment with methyldopa, $2 \mathrm{~g}$ daily.

*These patients were also receiving quinidine sulphate, $200 \mathrm{mg} 8$ hourly.

\section{Results}

Individual blood pressure readings in the lying, sitting and standing positions for both Group 1 and Group 2 patients are shown in Table 1. Table 2 shows the mean systolic and diastolic pressures in the three positions before, and at the end of 3,6 and 12 weeks treatment with propranolol in both groups of patients. It will be seen that there is a significant fall in systolic and diastolic blood pressure in both groups.

Throughout the trial, weight remained steady. In the Group 1 patients the frequency of anginal attacks, as judged by the number of glyceryl trinitrate tablets consumed, was reduced. Two patients in Group 2 who did not respond to methyldopa did not respond to propranolol either. Patients who showed no response to small doses showed a moderate reduction in blood pressure when the dose was increased to $400 \mathrm{mg}$ daily. The addition of propranolol to methyldopa augmented the hypotensive effects of methyldopa in all but two cases. Postural hypotension was not produced. The reduction in systolic and diastolic blood pressure was dose-dependent. It is interesting to note that three patients who were receiving quinidine showed marked reduction in blood pressure.

\section{Discussion}

The results of this trial confirm that propranolol has a significant hypotensive action both when used alone and as adjuvant therapy. The hypotensive action of propranolol was first described by Prichard \& Gillam (1964) following the earlier observations during a clinical trial of pronethalol in angina pectoris. Subsequently Prichard \& Gillam (1966) enlarged their study to include thirty-four patients who received propranolol for periods of 4-20 months. The drug was introduced slowly commencing with $10 \mathrm{mg}$ four times daily and increasing by increments of $10-20 \mathrm{mg} /$ dose to a maximum of $640 \mathrm{mg}$ 
TABLE 2

Mean blood pressures

\begin{tabular}{|c|c|c|c|c|c|c|}
\hline & $\begin{array}{l}\text { Pre- } \\
\text { treatment }\end{array}$ & Week 3 & Week 6 & Week 12 & $\begin{array}{l}\text { Standard } \\
\text { error of } \\
\text { difference } \\
\text { in means }\end{array}$ & Significance \\
\hline $\begin{array}{l}\text { Group } 1 \text { (eleven patients) } \\
\text { Daily dose of propranolol (mg) }\end{array}$ & 二 & 120 & $\frac{120}{240}$ & $\frac{240}{400}$ & & \\
\hline $\begin{array}{l}\text { Systolic } \\
\text { Lying } \\
\text { Sitting } \\
\text { Standing }\end{array}$ & $\begin{array}{l}200 \cdot 0 \\
202 \cdot 3 \\
196 \cdot 6\end{array}$ & $\begin{array}{l}196 \cdot 7 \\
196 \cdot 0 \\
194 \cdot 3\end{array}$ & $\begin{array}{l}189 \cdot 6 \\
186 \cdot 6 \\
188 \cdot 2\end{array}$ & $\begin{array}{l}178 \cdot 0 \\
175 \cdot 6 \\
173 \cdot 9\end{array}$ & $\begin{array}{l}3 \cdot 3 \\
3 \cdot 8 \\
3 \cdot 3\end{array}$ & $P<0.001$ \\
\hline $\begin{array}{l}\text { Diastolic } \\
\text { Lying } \\
\text { Sitting } \\
\text { Standing }\end{array}$ & $\begin{array}{l}110.5 \\
111.5 \\
110.9\end{array}$ & $\begin{array}{l}108 \cdot 3 \\
107 \cdot 2 \\
107 \cdot 4\end{array}$ & $\begin{array}{l}104 \cdot 0 \\
103 \cdot 6 \\
102 \cdot 4\end{array}$ & $\left.\begin{array}{l}96 \cdot 4 \\
96 \cdot 5 \\
94 \cdot 0\end{array}\right\}$ & $2 \cdot 5$ & $P<0.001$ \\
\hline $\begin{array}{l}\text { Group } 2 \text { (thirteen patients) } \\
\text { Daily dose of propranolol (mg) }\end{array}$ & - & 100 & 200 & 300 & & \\
\hline $\begin{array}{l}\text { Systolic } \\
\text { Lying } \\
\text { Sitting } \\
\text { Standing }\end{array}$ & $\begin{array}{l}214 \cdot 5 \\
212 \cdot 2 \\
211 \cdot 9\end{array}$ & $\begin{array}{l}208 \cdot 6 \\
207 \cdot 3 \\
206 \cdot 7\end{array}$ & $\begin{array}{l}204 \cdot 3 \\
203 \cdot 8 \\
201 \cdot 7\end{array}$ & $\begin{array}{l}198 \cdot 7 \\
197 \cdot 3 \\
194 \cdot 8\end{array}$ & $\begin{array}{l}2 \cdot 2 \\
1 \cdot 9 \\
2 \cdot 0\end{array}$ & $P<0.001$ \\
\hline $\begin{array}{l}\text { Diastolic } \\
\text { Lying } \\
\text { Sitting } \\
\text { Standing }\end{array}$ & $\begin{array}{l}123 \cdot 3 \\
122 \cdot 8 \\
122 \cdot 4\end{array}$ & $\begin{array}{l}119 \cdot 6 \\
119 \cdot 2 \\
118 \cdot 6\end{array}$ & $\begin{array}{l}115 \cdot 2 \\
114 \cdot 3 \\
112 \cdot 3\end{array}$ & $\begin{array}{l}108 \cdot 8 \\
108 \cdot 9 \\
107 \cdot 2\end{array}$ & $\begin{array}{l}1 \cdot 8 \\
1 \cdot 7 \\
1.4\end{array}$ & $P<0.001$ \\
\hline
\end{tabular}

daily. The blood pressure was well controlled in thirty-three of the thirty-four patients and in twenty-five of these propranolol was used alone.

A modest fall in blood pressure following the administration of propranolol to nine hypertensive out-patients was reported by Richards (1966). The dose of propranolol was increased progressively from $30-60 \mathrm{mg}$ daily to $150-300 \mathrm{mg}$ daily over 8-15 weeks, patients being assessed every 1-3 weeks and again 1 month after cessation of treatment. There was a mean fall of systolic pressure of $11 \mathrm{mmHg}(P>0.05)$ and $12 \mathrm{mmHg}$ in diastolic pressure $(P<0.01)$. Richards considered that propranolol was unlikely to have much therapeutic value when used alone.

Waal (1966) has reported results in sixty hypertensive patients all of whom had various cardiac arrhythmias. Propranolol was given in increasing doses until an anti-arrhythmic effect was observed and then held at that dose, except in twenty patients who were given more propranolol than was required to control the arrhythmia. Blood pressure was assessed as the mean of a 'day test' during which five to seven erect and supine measurements were made. Propranolol had a hypotensive action in fortyone of the sixty patients and in twenty-four of these the average fall in the day test was at least $25 \mathrm{mmHg}$ systolic and $15 \mathrm{mmHg}$ diastolic. In marked contrast to the findings of Prichard, Waal states that the hypotensive effect is observed on the 1st day of treatment and is not increased on prolonged treatment.

A comparison of the effect of propranolol, $80 \mathrm{mg}$ daily and $240 \mathrm{mg}$ daily, with hydrochlorothiazide, $50 \mathrm{mg}$ daily, has been made by Paterson \& Dollery (1966) in twelve previously untreated hypertensive patients. Each treatment was given to the patients for 6 weeks, the order of allocation being randomized. Propranolol, $240 \mathrm{mg}$ daily, was found to have a non-postural hypotensive effect indistinguishable from that of hydrochlorothiazide, $50 \mathrm{mg}$ daily. Zacharias (1966, 1967 personal communication) has found a mean reduction in systolic pressure of $30 \mathrm{mmHg}$ and diastolic of $15 \mathrm{mmHg}$ in ninety-five patients treated for up to 2 years. All the patients received thiazide diuretics in addition to propranolol. Thirty-six patients were 'well controlled' (mean diastolic blood pressure of $<90 \mathrm{mmHg}$ ) and twenty-seven patients 'moderately controlled' (mean diastolic blood pressure, 95-105 $\mathrm{mmHg}$ )

The mode of action of propranolol in hypertension is not established. Waal (1966) pointed 
out the similarity in hypotensive action of quinidine and propranolol in ten of her series and suggested that the hypotensive effect of propranolol is mediated by its quinidine-like effect rather than by beta-receptor blockade. In this connection it is interesting to note that three of our patients (Nos. 1, 5 and 6 in Group 1) who were receiving quinidine for an arrhythmia showed a substantial fall in blood pressure when propranolol was given as well. On the other hand Prichard (Prichard \& Gillam, 1964) has suggested that the hypotensive action is directly related to cardiac beta-receptor blockade. During any activity various stimuli are responsible for transient increase in blood pressure and heart rate and these may be prevented by beta-receptor blockade. For example, the overshoot phenomenon of Valsalva's manoeuvre is reduced by propranolol. Prichard postulates that carotid sinus, aortic arch and other baroceptors are gradually 'damped down' to regulate blood pressure at a lower level. The significant fact is that peripheral vascular responses are not impaired as seen in the virtual absence of postural hypotension during treatment with propranolol. It has recently been suggested by Horobin (1966) that the baroceptors become 'adapted' to high pressure in essential hypertension and that this adaptation may in fact be the primary factor in this condition. By readapting this mechanism it may be possible to set the control of pressure to more normal limits.

\section{Acknowledgments}

We wish to thank Dr R. Fletcher and Dr R. W. Meikle for allowing us to study these patients and we are grateful to Mr Colin Clark of Statistics Section, I.C.I. Pharmaceuticals Division for statistical advice.

\section{References}

Horobin, D.F. (1966) Hypothesis: A theory of hypertension. Lancet, i, 574.

Paterson, J.W. \& Dollery, C.T. (1966) Effect of propranolol in mild hypertension. Lancet, ii, 1148.

Prichard, B.N.C., Dickinson, C.J., Alleyne, G.A.Q. HuRST, P., Hill, I.D., RosenHeim, M.L.\& LAURENCE, D.R. (1964) Effect of pronethalol in agina pectoris. Brit. med. $J$. i, 1277.

Prichard, B.N.C. \& Gillam, P.M.S. (1964) Use of propranolol in treatment of hypertension. Brit. med. J. ii, 725.

Prichard, B.N.C. \& Gillam, P.M.S. (1966) Propranol in hypertension Amer. J. Cardiol. 18, 387.

RichardS, F.A. (1966) Propranolol in hypertension. Amer. J. Cardiol. 18, 384.

WAAL, H.J. (1966) Hypotensive action of propranolol. Clin. pharmacol. Ther. 7, 588

ZACHARIAS, F.J. (1966) Discussion in 'Symposium on Beta Adrenergic Receptor Blockade'. Amer. J. Cardiol. 18, 392. 